\title{
Effect of Bexarotene on Platelet Activation and Apoptosis
}

\author{
Hang Cao Rosi Bissinger $^{\mathrm{a}} \quad$ Anja T. Umbacha Meinrad Gawaz $^{\mathrm{a}} \quad$ Florian Lang ${ }^{\mathrm{b}}$ \\ a Department of Internal Medicine III, ${ }^{b}$ Department of Physiology I, Eberhard-Karls-University, Tuebingen, \\ Germany
}

\section{Key Words}

Thrombin - Collagen related peptide Platelet activation - Degranulation - Integrin • Cytosolic $\mathrm{Ca}^{2+}$ concentration $\cdot$ Caspase $\cdot$ Phosphatidylserine

\begin{abstract}
Background/Aims: The retinoid X receptor (RXRs) stimulator Bexarotene ((4-[1-(3,5,5,8,8-pentamethyl-5,6,7,8-tetrahydro-2-naphthyl)ethynyl] benzoic acid) is used for the treatment of several malignancies. Bexarotene is at least in part effective by stimulation of apoptosis of tumor cells. Moreover, Bexarotene triggers eryptosis, the suicidal death of erythrocytes. Similar to erythrocytes, blood platelets lack nuclei but are nevertheless able to enter an apoptosis-like phenotype, characterized by caspase activation, cell shrinkage and cell membrane scrambling with phosphatidylserine translocation to the cell surface. Platelet apoptosis is triggered by increase of cytosolic $\mathrm{Ca}^{2+}$-activity $\left(\left[\mathrm{Ca}^{2+}\right]\right)$, which further leads to degranulation and integrin activation. Platelet activation and apoptosis could be elicited by thrombin or collagen related peptide (CRP). The present study explored whether treatment of platelets with bexarotene modifies platelet activation and apoptosis following exposure to thrombin or CRP. Methods: Platelets isolated from wild-type mice were exposed for 30 minutes to bexarotene $(6 \mu \mathrm{g} / \mathrm{ml})$ without or with an additional treatment with thrombin $(0.01 \mathrm{U} / \mathrm{ml})$ or CRP $(2 \mu \mathrm{g} / \mathrm{ml}$ or $5 \mu \mathrm{g} / \mathrm{ml})$. Flow cytometry was employed to estimate cytosolic $\mathrm{Ca}^{2+}$-activity $\left(\left[\mathrm{Ca}^{2+}\right]_{\mathrm{i}}\right)$ from Fluo-3 fluorescence, platelet degranulation from P-selectin abundance, integrin activation from $\alpha_{\text {IIb }} \beta_{3}$ integrin abundance, caspase activity utilizing an Active Caspase-3 Staining kit, phosphatidylserine abundance from annexin-V-binding, and relative platelet volume from forward scatter. Results: In the absence of thrombin or CRP, the administration of bexarotene slightly but significantly increased $\left[\mathrm{Ca}^{2+}\right]_{i^{\prime}}$ but did not significantly modify P-selectin abundance, activated $\alpha_{\mathbb{I b}} \beta_{3}$ integrin, annexin-V-binding, cell volume, or caspase activity. Exposure of platelets to thrombin or CRP was followed by significant increase of $\left[\mathrm{Ca}^{2+}\right]_{\mathrm{i}}$ P-selectin abundance, active $\alpha_{\mathbb{I b}} \beta_{3}$ integrin, annexin-V-binding, and caspase activity. The effects of thrombin on $\left[\mathrm{Ca}^{2+}\right]_{i^{\prime}}$, annexin-V-binding, cell volume, and caspase activity as well as the effects of CRP on $\left[\mathrm{Ca}^{2+}\right]_{i^{\prime}}$ P-selectin abundance, activated $\alpha_{\text {IIb }} \beta_{3}$ integrin, annexin-V-binding, cell volume, and caspase activity were significantly augmented in the presence of bexarotene. Conclusions: Bexarotene sensitizes blood platelets for thrombin and/or CRP induced activation and apoptosis.
\end{abstract}

H. Cao and R. Bissinger contributed equally and thus share first authorship. 


\section{Introduction}

Bexarotene ((4-[1-(3,5,5,8,8-pentamethyl-5,6,7,8-tetrahydro-2-naphthyl)ethynyl] benzoic acid) [1,2], a stimulator of retinoid X receptors (RXRs) [1-8], has previously been shown to counteract tumor growth [2]. Bexarotene is thus used for the treatment of several malignancies such as cutaneous T-cell lymphoma (CTCL) [4, 6-29], non-small cell lung cancer [13, $30,31]$, and breast cancer [13, 32-34]. In animals, bexarotene proved to be effective in colon cancer [35], breast cancer [8, 36], and lung cancer [37]. Bexarotene has further been used in psoriasis [38]. Bexarotene may confer neuroprotection in traumatic brain injury [39] and reverse neurodegeneration [40].

The effects of bexarotene on tumor growth result at least in part from stimulation of apoptosis [4-6, 8, 11, 18, 29, 35-37, 41-46]. Moreover, bexarotene triggers eryptosis, the suicidal erythrocyte death [47].

Similar to nucleated cells and erythrocytes, blood platelets may enter an apoptosislike phenotype involving caspase activation, cell shrinkage, and cell membrane scrambling with phosphatidylserine translocation to the cell surface $[48,49]$. Platelets participate in the orchestration of primary hemostasis following vascular injury and contribute to the pathophysiology of arterial thrombosis, vascular inflammation and atherogenesis [50, 51]. Platelets are activated by an increase of cytosolic $\mathrm{Ca}^{2+}$ concentration $\left(\left[\mathrm{Ca}^{2+}\right]_{\mathrm{i}}\right)[52]$, which may result from $\mathrm{Ca}^{2+}$ release from intracellular stores [53] and subsequent store operated $\mathrm{Ca}^{2+}$ entry (SOCE) due to activation of $\mathrm{Ca}^{2+}$ release-activated channel Orai1 in the plasma membrane [52-55].

To the best of our knowledge, nothing is known about an effect of bexarotene on platelet apoptosis. The present study thus explored, whether bexarotene influences platelet activation and/or apoptosis.

\section{Materials and Methods}

\section{Mice}

All animal experiments were conducted according to the German law for the welfare of animals and were approved by the authorities of the state of Baden-Württemberg. Experiments were performed with blood platelets isolated from wild type mice. The mice had free access to water and control chow (Ssniff, Soest, Germany).

\section{Preparation of mouse platelets}

Platelets were obtained from 10 - to 12 -week-old mice of either sex. The mice were anesthetized and $800 \mu \mathrm{l}$ blood was drawn from the retro-orbital plexus into tubes with $200 \mu \mathrm{l}$ acid-citrate-dextrose buffer before the mice were sacrificed [56]. Platelet rich plasma (PRP) was obtained by centrifugation at $260 \mathrm{~g}$ for 5 minutes. Afterwards, PRP was centrifuged at $640 \mathrm{~g}$ for 5 minutes to pellet the platelets. Where necessary apyrase (0.02 U/ml; Sigma-Aldrich) and prostaglandin $\mathrm{I}_{2}(0.5 \mu \mathrm{M}$; Calbiochem) were added to the PRP to prevent activation of platelets during isolation [57]. After two washing steps, the pellet of washed platelets was resuspended in modified Tyrode-HEPES buffer ( $\mathrm{pH} 7.4$, supplemented with $1 \mathrm{mM} \mathrm{CaCl}_{2}$ ). Where indicated, thrombin (Roche, Basel, Switzerland) or collagen related peptide (kindly provided by R. Farndale, University of Cambridge, Cambridge, UK) was added at the indicated concentrations.

\section{Cytosolic calcium}

For the measurement of the cytosolic $\mathrm{Ca}^{2+}$ concentration, the platelet preparation was washed once in Tyrode buffer ( $\mathrm{pH} 7.4$ ), stained with $3 \mu \mathrm{M}$ Fluo-3AM (Biotinium, USA) in the same buffer and incubated at $37^{\circ} \mathrm{C}$ for 30 minutes. Following the indicated experimental treatment, relative fluorescence was measured utilizing a BD FACS Calibur (BD Biosciences, Heidelberg, Germany) [58, 59].

P-selectin and activated integrin abundance

Fluorophore-labeled antibodies were utilized for the detection of P-selectin expression (Wug.E9-FITC) [60] and the active form of $\alpha_{\mathrm{Ib}} \beta_{3}$ integrin (JON/A-PE) [61]. Washed mouse platelets $\left(1 \times 10^{6}\right)$ were suspended 


\section{Cellular Physiology Cell Physiol Biochem 2017;42:838-847

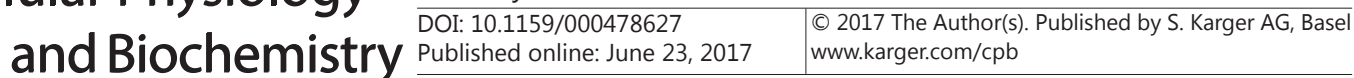 \\ Cao et al.: Bexarotene Sensitive Platelet Function}

in modified Tyrode buffer ( $\mathrm{pH} 7.4$ ) containing $1 \mathrm{mM} \mathrm{CaCl}_{2}$ and antibodies (1:10 dilution). They were subsequently subjected to the respective treatments for the indicated time periods at room temperature (RT). The reaction was stopped by addition of PBS and the samples were immediately analyzed on a BD FACSCalibur.

\section{Caspase-3 activity}

Caspase 3 activity was determined utilizing a CaspGlow Fluorescein Active Caspase-3 Staining kit from BioVision (CA, USA) according to the manufacturer's instruction. Fluorescence intensity was measured at an excitation wavelength of $488 \mathrm{~nm}$ and an emission wavelength of 530 in a BD FACSCalibur (BD Biosciences, USA).

\section{Phosphatidylserine exposure and forward scatter}

Phosphatidylserine exposure was determined in platelets with and without 10 minutes thrombin treatment. To this end, the platelet preparation was centrifuged at $660 \mathrm{~g}$ for 5 minutes followed by washing once with Tyrode buffer ( $\mathrm{pH}$ 7.4) with $1 \mathrm{mM} \mathrm{CaCl}_{2}$, staining with 1:20 dilution of Annexin-V FITC (Mabtag, Germany) in Tyrode buffer ( $\mathrm{pH} 7.4$ ) with $2 \mathrm{mM} \mathrm{CaCl}_{2}$ and incubation at $37^{\circ} \mathrm{C}$ for 30 minutes. Annexin-V binding reflecting surface exposure of phosphatidylserine was evaluated by flow cytometry utilizing a BD FACSCalibur. In parallel, the forward scatter (FSC) of the platelets was determined by flow cytometry as a measure of platelet size [62].

\section{Statistical analysis}

Data are provided as means $\pm \mathrm{SEM} ; n$ represents the number of independent experiments. All data were tested for significance using ANOVA with Tukey's test as post-test or unpaired student's t-test as appropriate. Results with $p<0.05$ were considered statistically significant.

\section{Results}

The present study explored whether bexarotene triggers activation and apoptosis of blood platelets. To this end, murine platelets were isolated from wild type mice and exposed to thrombin $(0.01 \mathrm{U} / \mathrm{ml})$ or collagen related peptide (CRP, $2 \mu \mathrm{g} / \mathrm{ml}$ or $5 \mu \mathrm{g} / \mathrm{ml}$ ) in the absence and presence of bexarotene $(6 \mu \mathrm{g} / \mathrm{ml})$.

Fig. 1. Bexarotene sensitive thrombin- and CRP-induced increase of cytosolic $\mathrm{Ca}^{2+}$ concentration. A-C. Original histogram overlays of Fluo-3 fluorescence reflecting cytosolic $\mathrm{Ca}^{2+}$ activity in murine platelets (A) without and (B) with a 100 seconds thrombin $(0.01 \mathrm{U} / \mathrm{ml})$ treatment or (C) with a 150 seconds CRP (2 $\mu \mathrm{g} / \mathrm{ml}$ ) treatment without (grey areas) and with (black lines) presence of bexarotene $(6 \mu \mathrm{g} / \mathrm{ml}, 30 \mathrm{~min})$. D. Arithmetic means \pm SEM $(n=6)$ of Fluo-3 fluorescence reflecting cytosolic

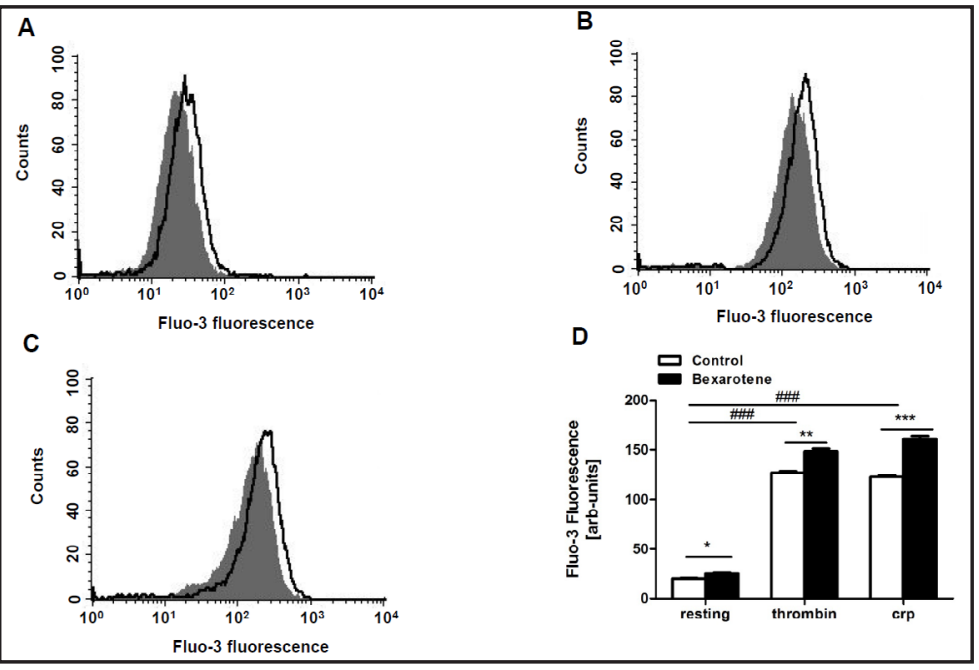

$\mathrm{Ca}^{2+}$ activity in murine platelets without (left bars, resting) and with a 100 seconds thrombin $(0.01 \mathrm{U} / \mathrm{ml})$ treatment (middle bars) or a 150 seconds CRP $(2 \mu \mathrm{g} / \mathrm{ml}$ ) treatment (right bars) in the absence (white bars) and presence (black bars) of $6 \mu \mathrm{g} / \mathrm{ml}$ bexarotene. ${ }^{*}(\mathrm{p}<0.05),{ }^{* *}(\mathrm{p}<0.01),{ }^{* * *}(\mathrm{p}<0.001)$ indicates statistically significant difference from absence of bexarotene, \#\#\#( $<<0.001)$ indicates statistically significant difference from absence of thrombin and CRP. 


\section{Cellular Physiology Cell Physiol Biochem 2017;42:838-847 \begin{tabular}{l|l|l} 
DOI: 10.1159/000478627 & O 2017 The Author(s). Published by S. Karger AG, Basel \\
www.karger.com/cpb
\end{tabular} \\ Cao et al:: Bexarotene Sensitive Platelet Function}

Fig. 2. Bexarotene sensitive thrombin- and CRP-induced increase of surface P-selectin. A-C. Original histogram overlays of P-selectin related fluorescence reflecting degranulation of murine platelets (A) without and (B) with a $15 \mathrm{~min}$ thrombin $(0.01 \mathrm{U} / \mathrm{ml})$ treatment or $(\mathrm{C})$ with a 15 min CRP $(2 \mu \mathrm{g} / \mathrm{ml})$ treatment without (grey areas) and with (black lines) presence of bexarotene (6 $\mu \mathrm{g} / \mathrm{ml}, 30 \mathrm{~min}$ ). D. Arithmetic means \pm SEM ( $\mathrm{n}=$ 6) of P-selectin related fluorescence reflecting degranulation of murine platelets without (left bars, resting) and with a $15 \mathrm{~min}$ thrombin $(0.01 \mathrm{U} / \mathrm{ml})$ treatment (middle bars) or a $15 \mathrm{~min}$ CRP (2 $\mathrm{\mu g}$ / $\mathrm{ml}$ ) treatment (right bars) in the absence (white bars) and presence (black bars) of $6 \mu \mathrm{g} / \mathrm{ml}$ bexarotene. ${ }^{* *}(\mathrm{p}<0.01)$ indicates statistically signifi-
B

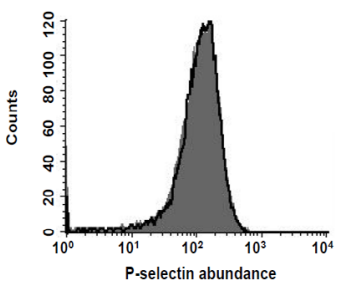

D
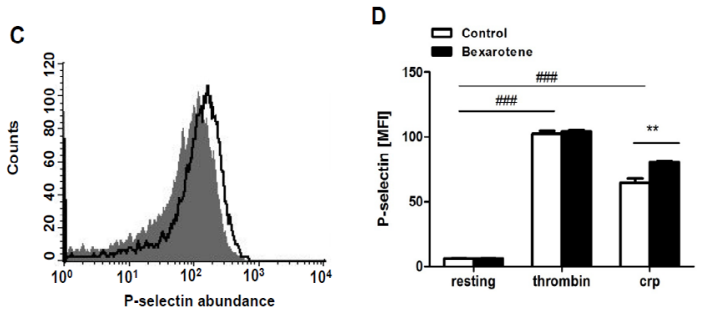

cant difference from absence of bexarotene, $\# \# \#(p<0.001)$ indicates statistically significant difference from absence of thrombin and CRP.

Fig. 3. Bexarotene sensitive thrombin- and CRP-induced increase of integrin $\alpha \operatorname{IIb} \beta 3$ activation. A-C. Original histogram overlays of activated $\alpha_{\mathrm{IIb}} \beta_{3}$ integrin related fluorescence in murine platelets (A) without and (B) with a 15 min thrombin $(0.01 \mathrm{U} / \mathrm{ml})$ treatment or $(\mathrm{C})$ with a $15 \mathrm{~min}$ CRP (2 $\mu \mathrm{g} / \mathrm{ml}$ ) treatment without (grey areas) and with (black lines) presence of bexarotene $(6 \mu \mathrm{g} /$ $\mathrm{ml}, 30 \mathrm{~min})$. D. Arithmetic means \pm SEM $(\mathrm{n}=6)$ of activated $\alpha_{\mathrm{IIb}} \beta_{3}$ integrin related fluorescence in murine platelets without (left bars, resting) and with a $15 \mathrm{~min}$ thrombin $(0.01 \mathrm{U} / \mathrm{ml})$ treatment (middle bars) or a $15 \mathrm{~min}$ CRP $(2 \mu \mathrm{g} / \mathrm{ml})$ treatment (right bars) in the absence (white bars) and presence (black bars) of $6 \mu \mathrm{g} / \mathrm{ml}$ bexarotene. $* *(\mathrm{p}<0.01)$ indicates statistically significant difference from absence of bexarotene, $\# \# \#(\mathrm{p}<0.001)$
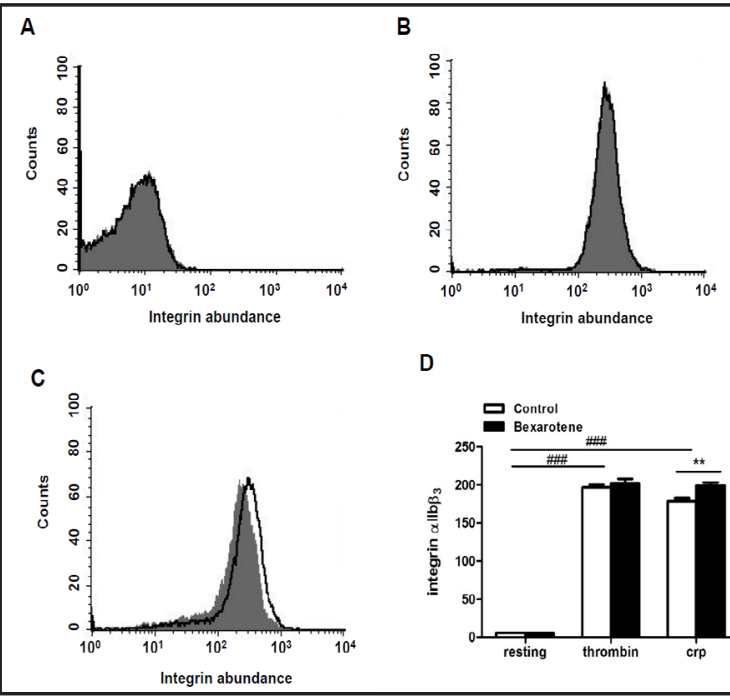

D

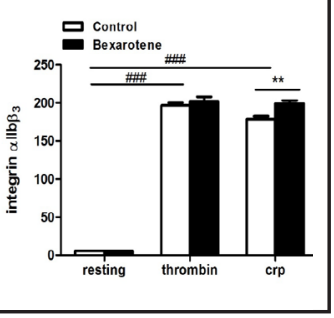
indicates statistically significant difference from absence of thrombin and CRP.

In a first series of experiments, cytosolic $\mathrm{Ca}^{2+}$ concentration $\left(\left[\mathrm{Ca}^{2+}\right]_{\mathrm{i}}\right)$ was determined utilizing Fluo-3 fluorescence. Prior to thrombin or CRP treatment, $\left[\mathrm{Ca}^{2+}\right]_{i}$ was slightly but significantly increased by bexarotene treatment (Fig 1). Exposure to thrombin or CRP was followed by a significant increase of $\left[\mathrm{Ca}^{2+}\right]_{\mathrm{i}}$ in platelets, an effect significantly augmented in the presence of bexarotene (Fig. 1).

Platelet degranulation was estimated from the increase of P-selectin abundance at the platelet surface, which was determined utilizing specific antibodies and flow cytometry. As illustrated in Fig. 2, the P-selectin abundance was negligible and not significantly modified by bexarotene treatment at the surface of resting platelets. Thrombin or CRP significantly increased the P-selectin abundance. The effect of CRP was significantly augmented in the presence of bexarotene (Fig. 2).

Similarly, the abundance of active integrin $\alpha_{\mathrm{IIb}} \beta_{3}$ at the surface of resting platelets was negligible both in the absence and presence of bexarotene (Fig. 3) and was significantly increased by thrombin or CRP treatment. Again, the effect of CRP was significantly augmented in the presence of bexarotene (Fig . 3). 


\section{Cellular Physiology Cell Physiol Biochem 2017;42:838-847 \begin{tabular}{l|l|l} 
DOI: 10.1159/000478627 & O 2017 The Author(s). Published by S. Karger AG, Basel \\
www.karger.com/cpb
\end{tabular}

Fig. 4. Bexarotene sensitive thrombinand CRP-induced caspase-3 activity. A-C. Original histogram overlays of fluorescence reflecting caspase-3 activity in murine platelets (A) without and (B) with a $10 \mathrm{~min}$ thrombin $(0.01 \mathrm{U} / \mathrm{ml})$ treatment or (C) with a $10 \mathrm{~min}$ CRP $(5 \mu \mathrm{g} /$ $\mathrm{ml}$ ) treatment without (grey areas) and with (black lines) presence of bexarotene $(6 \mu \mathrm{g} / \mathrm{ml}, 30 \mathrm{~min})$. D. Arithmetic means \pm SEM $(n=6)$ of the percentage of caspase-3-FITC positive murine platelets without (left bars, resting) and with a 10 min thrombin $(0.01 \mathrm{U} / \mathrm{ml})$ treatment (middle bars) or a $10 \mathrm{~min}$ CRP $(5 \mu \mathrm{g} / \mathrm{ml})$ treatment (right bars) in the absence (white bars) and presence (black bars) of $6 \mu \mathrm{g} / \mathrm{ml}$ bexarotene. ${ }^{*}(\mathrm{p}<0.05)$ indicates statistically significant difference from absence of bexarotene, \#\#\#(p<0.001) indicates statistically significant difference from absence of thrombin and CRP.

Fig. 5. Bexarotene sensitive thrombinand CRP-induced cell membrane scrambling. A-C. Original histogram overlays of annexin-V-binding reflecting phosphatidylserine abundance at the surface of murine platelets (A) without and (B) with a $10 \mathrm{~min}$ thrombin $(0.01 \mathrm{U} / \mathrm{ml})$ treatment or (C) with a $10 \mathrm{~min}$ CRP (5 $\mu \mathrm{g} / \mathrm{ml}$ ) treatment without (grey areas) and with (black lines) presence of bexarotene $(6 \mu \mathrm{g} / \mathrm{ml}, 30 \mathrm{~min})$. D. Arithmetic means \pm SEM $(n=6)$ of annexin-V-binding reflecting phosphatidylserine abundance at the surface of murine platelets without (left bars, resting) and with a $10 \mathrm{~min}$ thrombin $(0.01 \mathrm{U} / \mathrm{ml})$ treatment (middle bars) or a $10 \mathrm{~min}$ CRP (5 $\mu \mathrm{g} / \mathrm{ml})$ treatment (right bars) in the absence (white bars) and presence (black bars)

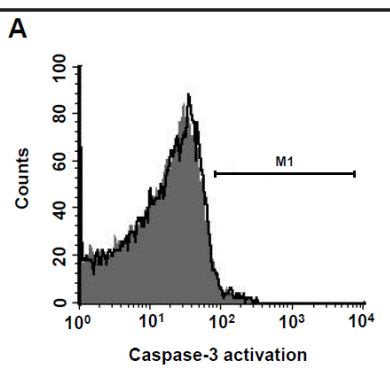

C

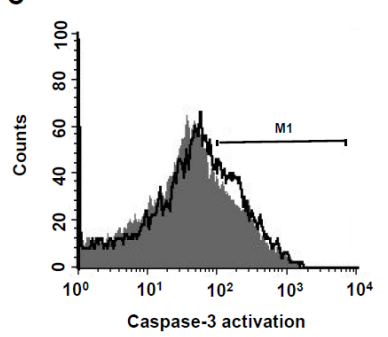

B

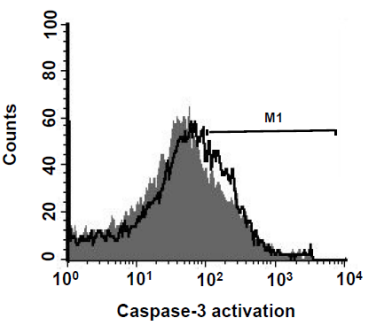

D

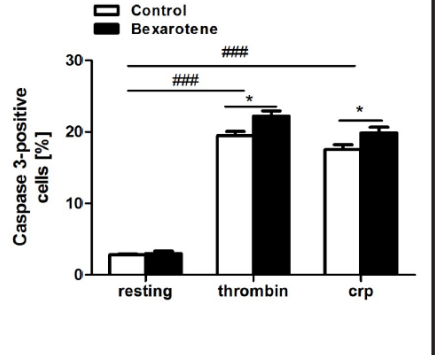
of $6 \mu \mathrm{g} / \mathrm{ml}$ bexarotene. ${ }^{*}(\mathrm{p}<0.05),{ }^{* * *}(\mathrm{p}<0.001)$ indicates statistically significant difference from absence of bexarotene, \#\#\#(p<0.001) indicates statistically significant difference from absence of thrombin and CRP.

A kit has been used for the detection of activated caspase 3. As illustrated in Fig. 4, caspase activity was negligible in untreated platelets, irrespective of the presence of bexarotene. Thrombin or CRP significantly enhanced caspase activity, an effect again significantly augmented in the presence of bexarotene (Fig. 4).

Phosphatidylserine abundance was estimated from annexin-V-binding. As illustrated in Fig. 5, the percentage of annexin-V positive platelets was again negligible in untreated platelets, irrespective of the presence of bexarotene. Thrombin or CRP significantly enhanced 
Fig. 6. Bexarotene sensitive thrombin- and CRP-induced cell shrinkage. A-C. Original histogram overlays of forward scatter reflecting cell volume of murine platelets (A) without and (B) with a 10 min thrombin $(0.01 \mathrm{U} /$ $\mathrm{ml}$ ) treatment or $(\mathrm{C})$ with a $10 \mathrm{~min}$ CRP $(5 \mu \mathrm{g} / \mathrm{ml})$ treatment without (grey areas) and with (black lines) presence of bexarotene $(6 \mu \mathrm{g} /$ $\mathrm{ml}, 30 \mathrm{~min})$. D. Arithmetic means \pm SEM $(n=6)$ of forward scatter reflecting cell volume of murine platelets without (left bars, resting) and with a $10 \mathrm{~min}$ thrombin $(0.01 \mathrm{U} / \mathrm{ml})$ treatment (middle bars) or a $10 \mathrm{~min}$

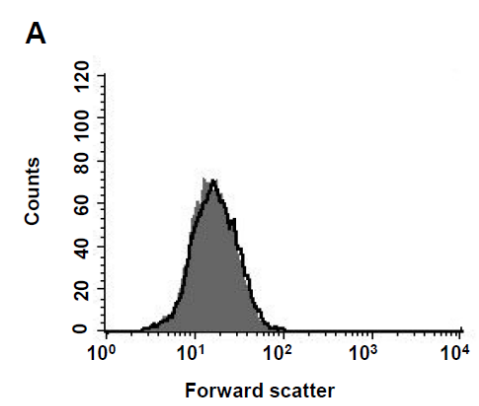

B

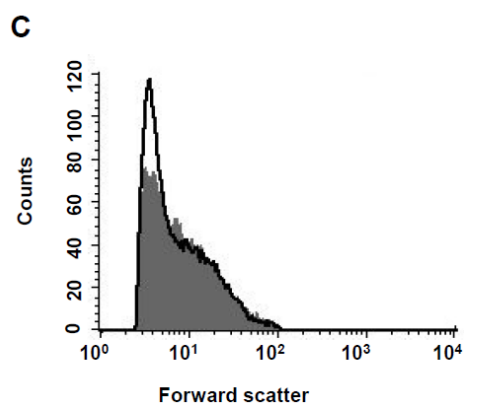

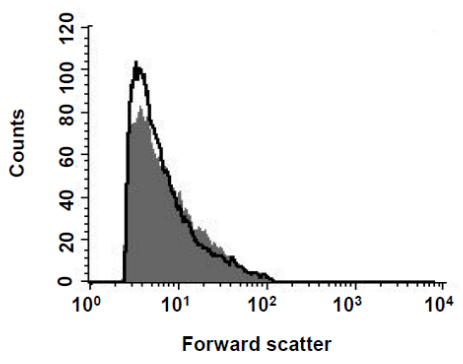

D

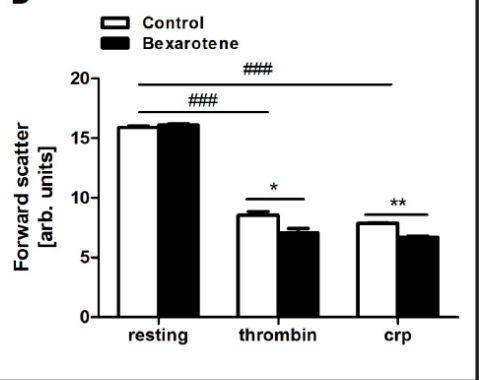

CRP $(5 \mu \mathrm{g} / \mathrm{ml}$ ) treatment (right bars) in the absence (white bars) and presence (black bars) of $6 \mu \mathrm{g} / \mathrm{ml}$ bexarotene. ${ }^{*}(\mathrm{p}<0.05),{ }^{* *}(\mathrm{p}<0.01)$ indicates statistically significant difference from absence of bexarotene, \#\#\# $(\mathrm{p}<0.001)$ indicates statistically significant difference from absence of thrombin and CRP.

the percentage of annexin- $V$ binding platelets, an effect again significantly augmented in the presence of bexarotene (Fig. 5).

Platelet volume was estimated from forward scatter, which was determined by flow cytometry. As illustrated in Fig. 6, thrombin or CRP treatment was followed by a marked decrease of forward scatter, an effect again significantly decreased in the presence of bexarotene (Fig. 6).

\section{Discussion}

The present observations demonstrate that bexarotene significantly augments the effect of thrombin on cytosolic $\mathrm{Ca}^{2+}$ activity $\left(\left[\mathrm{Ca}^{2+}\right]_{\mathrm{i}}\right)$, annexin-V-binding, cell volume, and caspase activity as well as the effect of collagen related peptide (CRP) on $\left[\mathrm{Ca}^{2+}\right]_{\mathrm{i}}$, P-selectin abundance, activated $\alpha_{\mathrm{II}} \beta_{3}$ integrin, annexin-V-binding, cell volume, and caspase activity. Thus, bexarotene sensitizes the platelets for the effects of thrombin and CRP. In the absence of thrombin and CRP bexarotene has only a slight, but statistically significant enhancing effect on $\left[\mathrm{Ca}^{2+}\right]_{\mathrm{i}^{*}}$

The augmenting effects of bexarotene on platelet activation and apoptosis may, at least in part, be secondary to the augmented increase of cytosolic $\mathrm{Ca}^{2+}$ activity $\left(\left[\mathrm{Ca}^{2+]}{ }_{\mathrm{i}}\right)[53,63]\right.$. An increase of $\left[\mathrm{Ca}^{2+}\right]_{\mathrm{i}}$ is followed by platelet activation and may thus foster the development of arterial thrombosis [52]. Increased $\left[\mathrm{Ca}^{2+}\right]_{\mathrm{i}}$ is further a stimulator of cell membrane scrambling with translocation of phosphatidylserine to the platelet surface [50, 64-66]. Phosphatidylserine abundance at the platelet surface fosters adhesion, coagulation and hemostasis [67]. Phosphatidylserine exposing platelets could be further bound to and engulfed by macrophages [68].

In conclusion, bexarotene augments the thrombin- and/or CRP-induced increase of $\left[\mathrm{Ca}^{2+}\right]_{i}$, P-selectin abundance, $\alpha_{\mathrm{II}} \beta_{3}$ integrin activity, annexin-V-binding, and caspase activity. Thus, bexarotene contributes to the triggering of platelet activation and apoptosis. 


\section{Cellular Physiology Cell Physiol Biochem 2017;42:838-847 \begin{tabular}{l|l} 
DOI: 10.1159/000478627 & and Biochemistry 2017 The Author(s). Published by S. Karger AG, Basel \\
wwww.karger.com/cpb
\end{tabular} Cao et al.: Bexarotene Sensitive Platelet Function}

\section{Acknowledgements}

We thank Lejla Subasic for meticulous preparation of the manuscript. Work of R.B. is supported by the Institutional Strategy of the University of Tübingen (Deutsche Forschungsgemeinschaft, ZUK63). This study was supported by the Deutsche Forschungsgemeinschaft - Klinische Forschergruppe [DFG-KFO 274] 'Platelets-Molecular Mechanisms and Translational Implications', as well as the Tuebingen Platelet Investigative Consortium (TuePIC) and Open Access Publishing Fund of Tuebingen University.

\section{Disclosure Statement}

The authors of this manuscript state that they have no conflicts of interest to declare.

\section{References}

1 Furmick JK, Kaneko I, Walsh AN, Yang J, Bhogal JS, Gray GM, Baso JC, Browder DO, Prentice JL, Montano LA, Huynh CC, Marcus LM, Tsosie DG, Kwon JS, Quezada A, Reyes NM, Lemming B, Saini P, van der Vaart A, Groy TL, Marshall PA, Jurutka PW, Wagner CE: Modeling, synthesis and biological evaluation of potential retinoid X receptor-selective agonists: novel halogenated analogues of 4-[1-(3,5,5,8,8-pentamethyl-5,6,7,8tetrahydro-2-naphthyl)ethynyl]benzoic acid (bexarotene). ChemMedChem 2012;7:1551-1566.

-2 Qi L, Guo Y, Zhang P, Cao X, Luan Y: Preventive and Therapeutic Effects of the Retinoid X Receptor Agonist Bexarotene on Tumors. Curr Drug Metab 2016;17:118-128.

-3 Asteria C: Treatment with retinoid X receptorgamma-selective ligand (bexarotene) may cause iatrogenic central hypothyroidism. Eur J Endocrinol 2000;142:324-325.

-4 Lowe MN, Plosker GL: Bexarotene. Am J Clin Dermatol 2000;1:245-250; discussion 251-242. Qu L, Tang X: Bexarotene: a promising anticancer agent. Cancer Chemother Pharmacol 2010;65:201-205. Querfeld C, Nagelli LV, Rosen ST, Kuzel TM, Guitart J: Bexarotene in the treatment of cutaneous T-cell lymphoma. Expert Opin Pharmacother 2006;7:907-915.

7 Scarisbrick JJ, Morris S, Azurdia R, Illidge T, Parry E, Graham-Brown R, Cowan R, Gallop-Evans E, Wachsmuth R, Eagle M, Wierzbicki AS, Soran H, Whittaker S, Wain EM: U.K. consensus statement on safe clinical prescribing of bexarotene for patients with cutaneous T-cell lymphoma. Br J Dermatol 2013;168:192-200.

8 Lin JH, Kim EJ, Bansal A, Seykora J, Richardson SK, Cha XY, Zafar S, Nasta S, Wysocka M, Benoit B, Rook AH, Fakharzadeh SS: Clinical and in vitro resistance to bexarotene in adult T-cell leukemia: loss of RXR-alpha receptor. Blood 2008;112:2484-2488.

-9 Assaf C, Bagot M, Dummer R, Duvic M, Gniadecki R, Knobler R, Ranki A, Schwandt P, Whittaker S: Minimizing adverse side-effects of oral bexarotene in cutaneous T-cell lymphoma: an expert opinion. $\mathrm{Br} \mathrm{J}$ Dermatol 2006;155:261-266.

10 Brennand S, Sutton VR, Biagi J, Trapani JA, Westerman D, McCormack CJ, Seymour JF, Kennedy G, Prince HM: Lack of apoptosis of Sezary cells in the circulation following oral bexarotene therapy. Br J Dermatol 2005;152:1199-1205.

-11 Budgin JB, Richardson SK, Newton SB, Wysocka M, Zaki MH, Benoit B, Rook AH: Biological effects of bexarotene in cutaneous T-cell lymphoma. Arch Dermatol 2005;141:315-321.

12 Duvic M: Bexarotene and DAB(389)IL-2 (denileukin diftitox, ONTAK) in treatment of cutaneous T-cell lymphomas: algorithms. Clin Lymphoma 2000;1 Suppl 1:S51-55.

13 Farol LT, Hymes KB: Bexarotene: a clinical review. Expert Rev Anticancer Ther 2004;4:180-188.

14 Gniadecki R, Assaf C, Bagot M, Dummer R, Duvic M, Knobler R, Ranki A, Schwandt P, Whittaker S: The optimal use of bexarotene in cutaneous T-cell lymphoma. Br J Dermatol 2007;157:433-440.

15 Gopaluni S, Perzova R, Abbott L, Farah R, Shrimpton A, Hutchison R, Poiesz BJ: CD8+ cutaneous T-cell lymphoma successfully treated with bexarotene: a case report and review of the literature. Am J Hematol 2008;83:744-746. 


\section{Cellular Physiology Cell Physiol Biochem 2017;42:838-847

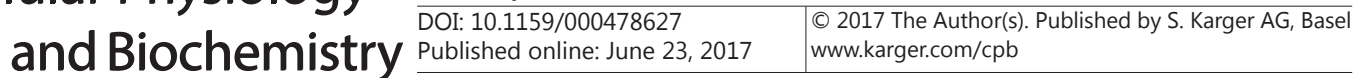 \\ Cao et al.: Bexarotene Sensitive Platelet Function}

16 Hamada T, Sugaya M, Tokura Y, Ohtsuka M, Tsuboi R, Nagatani T, Tani M, Setoyama M, Matsushita S, Kawai K, Yonekura K, Yoshida T, Saida T, Iwatsuki K: Phase I/II study of the oral retinoid X receptor agonist bexarotene in Japanese patients with cutaneous T-cell lymphomas. J Dermatol 2016;10.1111/13468138.13542

17 Hurst RE: Bexarotene ligand pharmaceuticals. Curr Opin Investig Drugs 2000;1:514-523.

18 Knol AC, Quereux G, Brocard A, Ballanger F, Khammari A, Nguyen JM, Dreno B: About the cutaneous targets of bexarotene in CTCL patients. Exp Dermatol 2010;19:e299-301.

19 Martin AG: Bexarotene gel: a new skin-directed treatment option for cutaneous T-cell lymphomas. J Drugs Dermatol 2003;2:155-167.

-20 McGinnis KS, Shapiro M, Vittorio CC, Rook AH, Junkins-Hopkins JM: Psoralen plus long-wave UV-A (PUVA) and bexarotene therapy: An effective and synergistic combined adjunct to therapy for patients with advanced cutaneous T-cell lymphoma. Arch Dermatol 2003;139:771-775.

21 McGinnis KS, Junkins-Hopkins JM, Crawford G, Shapiro M, Rook AH, Vittorio CC: Low-dose oral bexarotene in combination with low-dose interferon alfa in the treatment of cutaneous T-cell lymphoma: clinical synergism and possible immunologic mechanisms. J Am Acad Dermatol 2004;50:375-379.

22 Panchal MR, Scarisbrick JJ: The utility of bexarotene in mycosis fungoides and Sezary syndrome. Onco Targets Ther 2015;8:367-373.

23 Pileri A, Delfino C, Grandi V, Pimpinelli N: Role of bexarotene in the treatment of cutaneous T-cell lymphoma: the clinical and immunological sides. Immunotherapy 2013;5:427-433.

24 Quereux G, Saint-Jean M, Peuvrel L, Brocard A, Knol AC, Dreno B: Bexarotene in cutaneous T-cell lymphoma: third retrospective study of long-term cohort and review of the literature. Expert Opin Pharmacother 2013;14:1711-1721.

25 Sherman SI: Etiology, diagnosis, and treatment recommendations for central hypothyroidism associated with bexarotene therapy for cutaneous T-cell lymphoma. Clin Lymphoma 2003;3:249-252.

-26 Singh F, Lebwohl MG: Cutaneous T-cell lymphoma treatment using bexarotene and PUVA: a case series. J Am Acad Dermatol 2004;51:570-573.

27 Steinhoff M, Beyer M, Roewert-Huber J, Lukowsky A, Assaf C, Sterry W: Complete clinical remission of tumor-stage mycosis fungoides after acute extensive skin necroses, granulomatous reaction, and fever under treatment with bexarotene, vorinostat, and high-dose fenofibrate. J Am Acad Dermatol 2008;58:S8891.

28 Wong SF: Oral bexarotene in the treatment of cutaneous T-cell lymphoma. Ann Pharmacother 2001;35:1056-1065.

29 Zhang C, Hazarika P, Ni X, Weidner DA, Duvic M: Induction of apoptosis by bexarotene in cutaneous T-cell lymphoma cells: relevance to mechanism of therapeutic action. Clin Cancer Res 2002;8:1234-1240.

-30 Dragnev KH, Petty WJ, Shah SJ, Lewis LD, Black CC, Memoli V, Nugent WC, Hermann T, Negro-Vilar A, Rigas JR, Dmitrovsky E: A proof-of-principle clinical trial of bexarotene in patients with non-small cell lung cancer. Clin Cancer Res 2007;13:1794-1800.

-31 Rigas JR, Dragnev KH: Emerging role of rexinoids in non-small cell lung cancer: focus on bexarotene. Oncologist 2005;10:22-33.

-32 Kim T, Lau J, Erban J: Lack of uniform diagnostic criteria for inflammatory breast cancer limits interpretation of treatment outcomes: a systematic review. Clin Breast Cancer 2006;7:386-395.

-33 Kong JN, He Q Wang G, Dasgupta S, Dinkins MB, Zhu G, Kim A, Spassieva S, Bieberich E: Guggulsterone and bexarotene induce secretion of exosome-associated breast cancer resistance protein and reduce doxorubicin resistance in MDA-MB-231 cells. Int J Cancer 2015;137:1610-1620.

34 Yen WC, Lamph WW: The selective retinoid X receptor agonist bexarotene (LGD1069, Targretin) prevents and overcomes multidrug resistance in advanced breast carcinoma. Mol Cancer Ther 2005;4:824-834.

-35 Janakiram NB, Mohammed A, Zhang Y, Brewer M, Bryant T, Lightfoot S, Steele VE, Rao CV: Chemopreventive efficacy of raloxifene, bexarotene, and their combination on the progression of chemically induced colon adenomas to adenocarcinomas in rats. Cancer Prev Res (Phila) 2013;6:1251-1261.

-36 Abba MC, Hu Y, Levy CC, Gaddis S, Kittrell FS, Zhang Y, Hill J, Bissonnette RP, Medina D, Brown PH, Aldaz CM: Transcriptomic signature of bexarotene (rexinoid LGD1069) on mammary gland from three transgenic mouse mammary cancer models. BMC Med Genomics 2008;1:40.

37 Wang Y, Wen W, Yi Y, Zhang Z, Lubet RA, You M: Preventive effects of bexarotene and budesonide in a genetically engineered mouse model of small cell lung cancer. Cancer Prev Res (Phila) 2009;2:1059-1064. 


\section{Cellular Physiology Cell Physiol Biochem 2017;42:838-847 and Biochemistry Published online: June 23, $2017 \quad \begin{aligned} & \text { DOI 10159/2017 The Author(s). Published by S. Karger AG, Basel } \\ & \text { www.karger.com/cpb }\end{aligned}$ \\ Cao et al.: Bexarotene Sensitive Platelet Function}

38 Smit JV, Franssen ME, de Jong EM, Lambert J, Roseeuw DI, De Weert J, Yocum RC, Stevens VJ, van De Kerkhof PC: A phase II multicenter clinical trial of systemic bexarotene in psoriasis. J Am Acad Dermatol 2004;51:249-256.

-39 Zhong J, Cheng C, Liu H, Huang Z, Wu Y, Teng Z, He J, Zhang H, Wu J, Cao F, Jiang L, Sun X: Bexarotene protects against traumatic brain injury in mice partially through apolipoprotein E. Neuroscience 2017;343:434-448.

$\$ 40$ Tousi B: The emerging role of bexarotene in the treatment of Alzheimer's disease: current evidence. Neuropsychiatr Dis Treat 2015;11:311-315.

-41 Shilkaitis A, Bratescu L, Green A, Yamada T, Christov K: Bexarotene induces cellular senescence in MMTVNeu mouse model of mammary carcinogenesis. Cancer Prev Res (Phila) 2013;6:299-308.

42 Talpur R, Vu J, Bassett R, Stevens V, Duvic M: Phase I/II randomized bilateral half-head comparison of topical bexarotene 1\% gel for alopecia areata. J Am Acad Dermatol 2009;61:592.e591-599.

-43 Wagner CE, Jurutka PW, Marshall PA, Groy TL, van der Vaart A, Ziller JW, Furmick JK, Graeber ME, Matro E, Miguel BV, Tran IT, Kwon J, Tedeschi JN, Moosavi S, Danishyar A, Philp JS, Khamees RO, Jackson JN, Grupe DK, Badshah SL, Hart JW: Modeling, synthesis and biological evaluation of potential retinoid X receptor (RXR) selective agonists: novel analogues of 4-[1-(3,5,5,8,8-pentamethyl-5,6,7,8-tetrahydro-2-naphthyl) ethynyl]benzoic acid (bexarotene). J Med Chem 2009;52:5950-5966.

44 Ying SX, Seal S, Abbassi N, Hockenbery DM, Kiem HP, Li X, Pagel JM, Gopal AK, Deeg HJ: Differential effects of bexarotene on intrinsic and extrinsic pathways in TRAIL-induced apoptosis in two myeloid leukemia cell lines. Leuk Lymphoma 2007;48:1003-1014.

45 Wang Y, Rong J, Zhang J, Liu Y, Meng X, Guo H, Liu H, Chen L: Morphology, in vivo distribution and antitumor activity of bexarotene nanocrystals in lung cancer. Drug Dev Ind Pharm 2017;43:132-141.

-46 Zhang Q, Pan J, Zhang J, Liu P, Chen R, Chen DR, Lubet R, Wang Y, You M: Aerosolized bexarotene inhibits lung tumorigenesis without increasing plasma triglyceride and cholesterol levels in mice. Cancer Prev Res (Phila) 2011;4:270-276.

47 Al Mamun Bhuyan A, Bissinger R, Cao H, Lang F: Triggering of Suicidal Erythrocyte Death by Bexarotene. Cell Physiol Biochem 2016;40:1239-1251.

48 Gyulkhandanyan AV, Mutlu A, Freedman J, Leytin V: Markers of platelet apoptosis: methodology and applications. J Thromb Thrombolysis 2012;33:397-411.

49 Lebois M, Josefsson EC: Regulation of platelet lifespan by apoptosis. Platelets 2016;27:497-504.

50 Borst O, Munzer P, Gatidis S, Schmidt EM, Schonberger T, Schmid E, Towhid ST, Stellos K, Seizer P, May AE, Lang F, Gawaz M: The inflammatory chemokine CXC motif ligand 16 triggers platelet activation and adhesion via CXC motif receptor 6-dependent phosphatidylinositide 3-kinase/Akt signaling. Circ Res 2012;111:1297-1307.

51 Gawaz M: Role of platelets in coronary thrombosis and reperfusion of ischemic myocardium. Cardiovasc Res 2004;61:498-511.

52 Bergmeier W, Stefanini L: Novel molecules in calcium signaling in platelets. J Thromb Haemost 2009;7 Suppl 1:187-190.

-53 Varga-Szabo D, Braun A, Nieswandt B: Calcium signaling in platelets. J Thromb Haemost 2009;7:10571066.

54 Braun A, Varga-Szabo D, Kleinschnitz C, Pleines I, Bender M, Austinat M, Bosl M, Stoll G, Nieswandt B: Orai1 (CRACM1) is the platelet SOC channel and essential for pathological thrombus formation. Blood 2009;113:2056-2063.

55 Wang Y, Deng X, Gill DL: Calcium signaling by STIM and Orai: intimate coupling details revealed. Sci Signal 2010;3:pe42.

56 Pelzl L, Fakhri H, Umbach AT, Gawaz M, Paulmichl M, Lang F: Sgk1 sensitive pendrin expression in murine platelets. Cell Physiol Biochem 2013;32:210-220.

57 Liu G, Liu G, Alzoubi K, Chatterjee M, Walker B, Munzer P, Luo D, Umbach AT, Elvira B, Chen H, Voelkl J, Foller M, Mak TW, Borst O, Gawaz M, Lang F: CD44 sensitivity of platelet activation, membrane scrambling and adhesion under high arterial shear rates. Thromb Haemost 2015;115:

-58 Towhid ST, Tolios A, Munzer P, Schmidt EM, Borst O, Gawaz M, Stegmann E, Lang F: Stimulation of platelet apoptosis by balhimycin. Biochem Biophys Res Commun 2013;435:323-326. 


\section{Cellular Physiology Cell Physiol Biochem 2017;42:838-847 \begin{tabular}{ll|l} 
and Biochemistry & $\begin{array}{l}\text { DOI: 10.1159/000478627 } \\
\text { Published online: June 23, } 2017\end{array}$ & $\begin{array}{l}\text { O 2017 The Author(s). Published by S. Karger AG, Basel } \\
\text { www.karger.com/cpb }\end{array}$ \\
\cline { 2 - 3 }
\end{tabular} \\ Cao et al.: Bexarotene Sensitive Platelet Function}

59 Liu G, Liu G, Chen H, Alzoubi K, Umbach AT, Gawaz M, Stournaras C, Lang F: Rapid Upregulation of Orai1 Abundance in the Plasma Membrane of Platelets Following Activation with Thrombin and Collagen Related Peptide. Cell Physiol Biochem 2015;37:1759-1766.

60 Liu G, Cao H, Liu G, Heinzmann D, Chen H, Umbach AT, Gawaz M, Lang F: Effect of Lysosomotropic Polyamineoxidase Inhibitor MDL-72527 on Platelet Activation. Cell Physiol Biochem 2016;38:1695-1702.

61 Liu G, Liu G, Chatterjee M, Umbach AT, Chen H, Gawaz M, Lang F: Influence of gamma-Secretase Inhibitor 24-Diamino-5-Phenylthiazole DAPT on Platelet Activation. Cell Physiol Biochem 2016;38:726-736.

-62 Liu G, Liu G, Chen H, Borst O, Gawaz M, Vortkamp A, Schreiber R, Kunzelmann K, Lang F: Involvement of Ca2+ Activated Cl- Channel Ano6 in Platelet Activation and Apoptosis. Cell Physiol Biochem 2015;37:19341944.

63 Lang F, Munzer P, Gawaz M, Borst O: Regulation of STIM1/Orai1-dependent Ca2+ signalling in platelets. Thromb Haemost 2013;110:925-930.

64 Harper MT, Poole AW: Store-operated calcium entry and non-capacitative calcium entry have distinct roles in thrombin-induced calcium signalling in human platelets. Cell Calcium 2011;50:351-358.

65 Mahaut-Smith MP: A role for platelet TRPC channels in the Ca2+ response that induces procoagulant activity. Sci Signal 2013;6:pe23.

66 Mushtaq M, Nam TS, Kim UH: Critical role for CD38-mediated Ca2+ signaling in thrombin-induced procoagulant activity of mouse platelets and hemostasis. J Biol Chem 2011;286:12952-12958.

67 Lhermusier T, Chap H, Payrastre B: Platelet membrane phospholipid asymmetry: from the characterization of a scramblase activity to the identification of an essential protein mutated in Scott syndrome. J Thromb Haemost 2011;9:1883-1891.

68 Badlou BA, Wu YP, Smid WM, Akkerman JW: Platelet binding and phagocytosis by macrophages. Transfusion 2006;46:1432-1443. 